\title{
CORRUPTION, TRADITION AND CHANGE
}

\author{
Theodore M. Smith
}

In January 1970 Indonesian student organizations took to the Djakarta streets to protest corruption in their government. It was the strongest anti-corruption outburst in the 25-year history of the Republic and threatened to upset the political stability which President Suharto had sought to establish as a basis for national economic growth. Special troops from the Army handled the immediate challenge, but as a longer term palliative the President appointed a special Commission of Four (Komisi IV) to review the problem and make concrete suggestions for improvement.

For several months the Commission held hearings in executive session and sifted through charges and evidence pertaining to corrupt practices while the press, students, and national political figures expressed their own views. I Subsequently, in his annual Independence Day speech to the nation, the President reviewed the recommendations of the Commission and boldly stated that, "There should no longer be any doubts about it. I myself will lead the fight against corruption." 2

This personal statement partially succeeded in defusing the issue, enabling the regime to turn its resources away from shortrun political problems and back to longer-run economic policy considerations. But given the pervasive nature of the problem, corruption is certain to be a recurring issue. This article attempts to explain Indonesian corruption and in so doing, to review the kind of demands it makes on a regime preoccupied with the primary objectives of staying in power and promoting economic growth.

As applied here, the term "corruption" refers to the use of public resources for private purposes. This definition covers not only conventional monetary, but also political and administrative corruption as we11. An administrator who exploits his position to extract unofficial payments from investors (either foreign or domestic) is using

1. The presidential adviser to the Commission, former Vice-President Hatta, was quoted as saying that, "Corruption has become an Indonesian art," and that it is a "part of the culture." Indonesian Observer, July 2, 1970 , p. 1. Half-humorously, a columnist for the Djakarta Times suggested that the Ministry of Education and Culture estabilsh a division for corrpution, presumably in its Directorate General for Culture. July 3, 1970, p. 1 .

2. "Address of State by the President of the Republic of Indonesia Before the House of Representatives on the Eve of the 25 th Independence Day," August 16, 1970, Djakarta, p. 28. 
a public resource-his official position, prestige, status, and/or authority--for personal profit. Likewise, an official who appoints family and friends to lucrative government positions regardless of their abilities is using a public resource for private gain.

Corruption can be categorized in various other ways. One type of classification might use scale, starting with large manipulations at the top and descending to "speed money" and gifts of cigarettes at the bottom. ${ }^{3}$ This could lead to a useful qualitative distinction between high level and low level corruption, both within a single government organization and across various levels of the governmental system--national, provincial, district, sub-district and village.

A second kind of classification might distinguish types of resource diversion according to the method employed by the perpetrators. There are some officials who directly divert funds which are under their control, while others use their official authority to command unofficial payments from private parties seeking special privileges or governmental assistance. The former is stealing and constitutes a direct loss of state financial resources. The latter is bribery and represents the loss of a different kind of resource, the government's legitimacy, particularly in the eyes of some critical elite groups such as professionals, academics, students, and civil servants. Bribes may account for significant financial losses to the state as we11, since they frequently represent private payments in lieu of official tax or licensing obligations. In their present anti-corruption campaign, Indonesia's leaders seem to favor this distinction, and their statements indicate that they are primarily concerned with the first kind of deviation. At first glance this choice appears to be a case of misplaced priorities, but administrative convenience and "reach" probably governed the choice: far fewer people are involved in outright stealing than in bribery.

A third system of classification deals with the targets of corrupt practices. Regional economic planners from all of Indonesia's 26 provinces listed the following kinds of corruption:

TABLE I

Responses of 54 Regional Economic Planners to the Question: "What kind of corruption is most damaging to economic development?"a

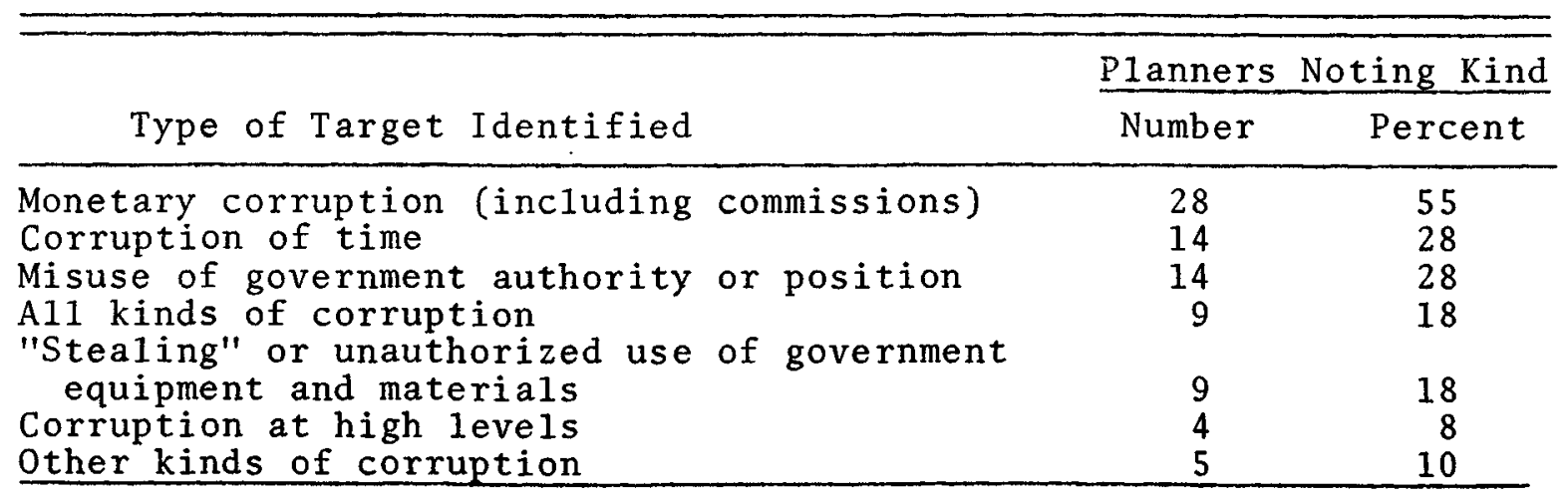

a. The data are based on the author's survey of provincial economic planners in August 1969.

3. "Speed money," or "lubricating money" (uang semir) as it is called 
This last classification is especially useful for two reasons. First, officials are interested in this classification and are willing to discuss it, thereby eliminating a major methodological problem for research. Second, such a breakdown can inform policy makers of the kinds of problems troubling particular constituencies, thus clarifying possible decision areas for government leaders.

\section{Causes of Corruption}

\section{Historical Variables}

Furnivall has written that the Netherlands Indies was practical1y free of corruption. ${ }^{4}$ While this view is corrobated by many Indonesians living today who are prone to credit the Japanese occupation government with introducing corruption, there is a wealth of evidence to show that it is incorrect. Prior to 1800 , the Dutch East India Company offered Indonesians flagnant examples of corrupt behavior. In the words of Clive Day, the men of the Company "were underpaid and exposed to every temptation that was offered by the combination of a weak native organization, extraordinary opportunities in trade, and an almost complete absence of checks from home or in Java... . Officials became rich by stealing from the company. Some forms of theft came in time to deserve a less harsh name, as they were so current and open that they could be regarded as legal."s

From the writings of Raffles and the numerous colonial reports cited by Day, it is clear that the demise of Company rule and the arrival of the Dutch Governor General at the turn of the nineteenth century resulted in an unavoidable widening of illicit practices. As colonial regulation and control expanded, both European and native officials indulged in obvious abuses, enjoying not only the specified percentage which was their right, but also a portion of most resources passing through their hands. When traditional services and payments due the native aristocratic officials were abolished in favor of Dutch-paid salaries, native officials had no alternative but to use illegal means if they wished to maintain the state of life to which they were accustomed. ${ }^{6}$ Other aristocratic (prijaji) Javanese bribed their way into remunerative positions dispensed by Dutch officials. ${ }^{7}$ And with the expansion of Dutch taxation on the

in Indonesia, is a small bribe offered on the assumption that some permission or necessary governmental action will either be waived or disposed of more quickly.

4. J. S. Furniva11, Colonial Policy and Practice: A Comparative Study of Burma and Netherlands India (London: Cambridge University Press, 1957), p. 269.

5. Clive Day, The Dutch in Java (London: Oxford University Press, 1966), pp. 100-103.

6. Ibid., pp. 299-300.

7. See John Smail's sections on Indonesian history in David J. Steinberg, ed., In Search of Southeast Asia: A Modern History (New York: Praeger, 1970), p. 147 . 
land and its produce, native officials as low as village headmen and their assistants took advantage of new opportunities for profiteering. In Java, "Some bekel (tax farmers) raised twenty-fold what they paid to their superiors. Their devices for extortion were innumerable."8 In West Sumatra, village adat (customary law) leaders "frequently had to be dismissed for fraud."9 Just as stealing from the Dutch East India Company in the eighteenth century came to be overlooked, so too, minor forms of extortion by native officials grew to be tolerated. "The little man never makes open complaint," said a native witness when asked about gross abuses during an 1850 investigation. ${ }^{10}$

Part of the difficulty in reaching agreement on the incidence of corruption during the colonial period is definitional. For example, the use of tax revenue for personal purposes, which may have been much commoner in pre-independence times, did not wholly violate the prijaji conscience. Soemarsaid Moertono, writing about statecraft in the Later Mataram Period (sixteenth to nineteenth centuries), provides good clues as to the type of administrative culture which the Dutch encountered in Java:

The maintenance of a department, office or institution was left wholly to the ability and moral considerations of the office-holder, a fact quite in harmony with a state organization in which personal authority played such a dominating role.

And further:

The finance system of Later Mataram can be called "salaryfinancing," for out of the salary which the official earned (entirely in the form of appanages called lungguh) he was expected to pay all the expenses entailed in the performance of his tasks and duties. ${ }^{11}$

In short, traditionally there was little differentiation between public and private money.

But subsequent1y, particularly with the rise of nationalism and the achievement of an Indoneisan state, claims to state resources increasingly became public claims and the private use of what were

8. Day, Dutch in Java, p. 33 .

9. B. Schrieke, Indonesian Sociological Studies (The Hague: W. Van Hoeve, 1955), I, p. 137 .

10. Day, Dutch in Java, p. 307 .

11. Soemarsaid Moertono, State and Statecraft in 01d Java: A Study of the Later Mataram Period, 16th to 19th Century (Ithaca: Corne11 Modern Indonesia Project, 1963), pp. 90 and 134. Many of these tasks and duties were social ones, and present cultural norms dictate that they still be performed today. But in modern, rational-legal terms, the use of government money for these functions is often considered corruption. Only a very few top officials receive budgetary subsidies for this purpose. 
now "public" funds became "corruption." Thus, the expansion of corruption in Indonesia, as in other new states, constitutes, in part, a new definition of corrupt practices rather than a change in traditional behavior. In the well-chosen words of Wertheim, ". . . a kind of public conduct hitherto considered normal was now looked at with other, more critical eyes."12

Another link between corruption and nationhood stems from revolutionary leaders' perceptions of the function of the state. In nearly all cases, and particularly in the case of Indonesia during the Guided Democracy period (1958-1965), the government's role in society-political, economic, and administrative--expanded very considerably. With this expansion came many new possibilities for corruption and bribery involving public officials.

These two points which link the rise of corruption as an issue with the early years of nationhood are not earthshaking, but they provide a corrective to Myrdal's uncritically gloomy assertion that corruption in post-independence Asia is increasing. ${ }_{3}$ Points of reference are important. For example, relative to the growth in personnel and functions which national bureaucracies have undergone, corruption may not in fact be "increasing."

\section{Cu1tural Variables}

For hundreds of years much of Java was effectively ruled by aristocrats who, as representatives of the kings, enjoyed patrimonial privileges not unlike those found in feudal Europe. Princely and regency offices were often hereditary and a percentage of crop yields was due their incumbents, as were domestic services known as pantjen. Daendels' attempt to instil the Napoleonic concept of government in Java faltered under the impact of the Java War (1825-1830), but eventually made headway at the end of the nineteenth century when many traditional privileges were reduced at al1 governmental leve1s, except at the base of Javanese civil administration, the village. Here no distinction was made between money that went to the treasury and that which did not; non-salaried village headmen collected taxes, paid themselves whatever they felt they deserved and used the remainder for the village needs. This practice was completely in harmony with patrimonial values.

In many Javanese villages this pattern has changed only slightly since independence. This means that for the villager who rises to

12. W. F. Wertheim, "Sociological Aspects of Corruption in Southeast Asia," in East-West Parallels: Sociological Approaches to Modern Asia (The Hague: W. Van Hoeve, 1964), p. 111. This point has been elaborated upon by James C. Scott in, "The Analysis of Corruption in Developing Nations," Comparative Studies in Society and History, 2, No. 3 (June 1969), pp. 318-319.

13. Gunnar Myrda1, Asian Drama (New York: Pantheon, 1968), II, p. 944 . 
the level of district or subdistrict officer today, traditionally accepted behavior and values suddenly become legaliy corrupt behavior and values. Since a majority of today's Indonesian civil servants were born and raised in villages and undoubtedly carried (and still carry) many of these traditional values into office with them, this normative conflict has an important bearing on bureaucratic behavior. ${ }^{14}$

TABLE II

Place of Birth and Childhood Residence of a Sample of Regional Officials by Class

\begin{tabular}{|c|c|c|c|c|}
\hline \multirow[t]{2}{*}{ Class of Civil Servant } & \multicolumn{2}{|c|}{ Place of Birth } & \multicolumn{2}{|c|}{$\begin{array}{l}\text { Age } 1 \text { to } 12 \text { Lived } \\
\text { Mostly in: }\end{array}$} \\
\hline & Village & City ${ }^{b}$ & Village & City \\
\hline Economic Planners & 32 & 22 & 30 & 24 \\
\hline Higher Level officials & 96 & 61 & 74 & 82 \\
\hline Lower Level Officials & 83 & 62 & 73 & 72 \\
\hline Subdistrict Officers & 202 & 52 & 171 & 83 \\
\hline Totals & $413(68 \%)$ & $197(32 \%)$ & $348(57 \%)$ & $261(43 \%)$ \\
\hline
\end{tabular}

a. The 54 regional economic planners surveyed are those referred to on page 22. The "Higher Level" (salary grade III and IV) and "Lower Level" (salary grade II) civil servants in the sample hold jobs in the provincial capitals of West Sumatra, South Sulawesi, and Central Java. They were drawn in approximately equal numbers from the Departments of Home Affairs, Finance, Education/Culture, and Public Works. The Subdistrict Officers, or Tjamat, were drawn from the same three provinces. This data and that in the following tables was obtained between October 1969 and April 1970.

b. City refers to kotamadya, which is the Indonesian equivalent of municipality. Though not based strictly on population, there are few large towns which are not accorded this status.

As Table II reveals, a clear majority of a representative sample of regional officials were born in and grew up in villages, indicating a strong potential link with the patrimonial value-system described so well by Geertz. ${ }^{15}$ While there is no good comparative data to show differences in Indonesian rural and urban values, powerful residues of patrimonial value structures can be found in most multi-generation urban dwellers. Thus the lack of congruence between civil servant

14. B. Soesarso, Korupsi di Indonesia (Djakarta: Bhratara, 1969), especially Chapter 10, "Redefinition of Morality."

15. Clifford Geertz, The Religion of Java (New York: The Free Press, 1960), Chapter 17 . 
values and legal-rational bureaucratic norms may be even more general than the data on place of birth and childhood suggest.

While the data and explanations presented above are not intended as an apology for corruption, they do go far to explain the dilemma faced by many government officials. Schooled in traditional village values, many of them entered the government directly at the time of Independence without benefit of value-changing higher education. Today they are either burdened with (sustained by?) these traditional values or else find themselves in a situation of increasing moral disorientation.

An understanding of the continuing significance of the traditional value system in Java also helps to explain why anti-corruption drives rarely proceed very far. Java's administrative culture is built around "a very intense concern for status: for smooth, constrained, hyperpolite behavior."16 To make direct charges of corrupt practices against individuals engenders a disagreeable, open conflict situation. It threatens a man's livelihood and status, that of his family, his staff, and possibly that of his organization. It may even go beyond that. Like a thread that begins to unrave 1 , the exposure of malpractices by one official may lead to the ordershattering implication of several others not even under suspicion. David Mitchell has suggested that most officials in the district which he studied were complicit in each others' corrupt practices (tahu-sama-tahu), and a recent case in the Central Java regency of Wonogiri offers a clear example of how this system sometimes works. ${ }^{17}$ For the typical Javanese, the psychic costs of direct interpersonal conflict and the dangers involved in leveling charges of corruption appear too high to encourage much of the aggressive behavior that is a sine qua non for successful anti-corruption drives. ${ }^{8}$

16. Clifford Geertz, The Social History of an Indonesian Town (Cambridge: MIT Press, 1965), p.79.

17. "Wanokalada: A Case Study in Local Administration," Bulletin of Indonesian Economic Studies, Ju1y 1970 , p. 83. For a review of events in Wonogiri, see "Sidang Korupsi 5 Pedjabat di Wonogiri," Kompas, September 9, 1970, p. 2.

18. Part of this general argument can also be found in the published conclusions of a seminar on "Corruption and Development" held in Djakarta and sponsored by the Student Council of the University of Indonesia, August 10-12, 1970. "Inventarisasi Pendapat 2 peserta Pane 1 Diskusi Tentang 'Korupsi dan Pembangunan" (mimeo). Seminar panelists explained the failure of the Indonesian public openly to criticize officials who are widely known to be involved in corrupt practices as follows: "The people have extraordinary respect for someone in authority. He is thought of as a superior and they do not want to take a critical attitude toward anything that he does. This seems to be the reason why this social stratum does not react to cases of corruption." 
Economic Factors

In the late 1950's, Dr. Hatta observed that, "Workers and government employees, whose wages and salaries are no longer adequate for their daily needs, are being exploited by enterprising adventurers who want to get rich quickly. . . Bribery and graft have become increasingly common, to the detriment of our community and country."19 Since early colonial times, insufficient salaries for Indonesian officials have been a continuing problem. The following table illustrates the current gap between basic government salaries (including official supplements in rupiahs which may run as high as 100 percent for senior officials) and minimal monthly rupiah requirements of various groups of civil servants. The figures demonstrate that, practically speaking, there is not a single official who can live by his government income alone.

\section{TABLE III (a)}

A Comparison of Minimal Monthly Salary Needs and Official Basic Monthly Incomes by

Classes of Civil Servants

\begin{tabular}{lcr}
\hline \multicolumn{1}{c}{$\begin{array}{c}\text { Type of Regiona1 } \\
\text { officia1 }\end{array}$} & $\begin{array}{c}\text { Stated Minimal } \\
\text { Monthly Needs } \\
\text { (Average) }\end{array}$ & $\begin{array}{c}\text { Official Basic } \\
\text { Monthly Income } \\
\text { (Average) }\end{array}$ \\
\hline Economic P1anners (54) & Rp. 15,132 & Rp. 8,514 \\
Higher Leve1 (157) & 20,028 & 11,268 \\
Lower Leve1 (146) & 16,434 & 7,050 \\
Subdistrict Officers (226) & 15,361 & 7,050 \\
\hline
\end{tabular}

a. To reach this figure the following allowances were added to the basic salary (gadji pokok): implementation allowance (tundjangan pelaksanaan), 20\%; "responsibility" a1lowance (tundjangan djabatan), $20 \%$; a rice allowance of approximately Rp. 40 per kilogram at 10 kilograms per family member; a spouse allowance of $5 \%$; and $2 \%$ for each child under 18 years of age. There is then a $10 \%$ standard deduction in the basic salary for health insurance and pensions.

Only a minority of officials receive the "responsibility" allowance, the maximum number being limited to $25 \%$ of the total employees in each department. The supplement is given to those in leadership positions, such as section and bureau heads. All officials, except for the lowest ranking (Salary Group I) receive the implementation allowance.

As an example of the monthly salary computation, here is the case of an official who is a bureau head in the Governor's office (South Sulawesi), has a master's degree, ten years of government

19. Mohammad Hatta, The Co-operative Movement in Indonesia (Ithaca: Corne11 University Press, 1957), pp. 84-85. 
service, a wife and five children.

\begin{tabular}{lr} 
Basic Salary & Rp. \\
Implementation allowance (20\%) & 1,000 \\
"Responsibility" allowance (20\%) & 1,008 \\
Rice allowance (70 kilograms x Rp. 40) & 2,800 \\
Wife allowance (5\%) & 252 \\
Children allowance (2\% x 5) Gross Income & 504 \\
Health/pension deduction (10\%) & Rp. 10,612 \\
& -504 \\
\hline
\end{tabular}

Total government income Rp. $10,108=$ $\$ 26.95 /$ month

Officials in the Department of Finance receive a premi each month ( $100 \%$ of their basic salaries) which adds about one-third to these figures and some departments have attached personnel incentives to their development projects-foremost among them being the Department of Public Works. The figures presented do not include housing and vehicles which are provided for a small minority of highlevel officials.

A11 of the data were gathered in the period October 1969 to April 1970 .

The data show that official income amounts to approximately half of essential monthly needs. Actual month1y expenditures, a more accurate indicator of perceived needs, run somewhat higher but cannot be precisely determined. However, a general picture of the present disparity between officials' government income and their expenditures is presented in Table III(b). Salaries and bonuses currently amount to about one-third of the amount most officials say they need to sustain their families' standard of living.

TABLE III (b)

Responses of Regional Officials to the Question:

"How large an increase in salary would

you need before you would decide to

give up your extra-governmental

jobs or before you could fulfill

the needs of your family?"

\begin{tabular}{|c|c|c|c|c|c|}
\hline Class of Civil Servant & $\begin{array}{l}2 \text { Times } \\
\text { or Less }\end{array}$ & 3 Times & 4 Times & 5 Times & $5+$ Times \\
\hline $\begin{array}{l}\text { Higher Level } \\
\text { (Salary Grades } 3 \& 4)\end{array}$ & 35 & 48 & 23 & 16 & 14 \\
\hline $\begin{array}{l}\text { Lower Leve } 1 \\
(\text { Salary Grade 2) }\end{array}$ & 34 & 39 & 22 & 14 & 17 \\
\hline $\begin{array}{l}\text { Subdistrict Officers } \\
\text { (Salary Grade } 2) \quad(207)\end{array}$ & 55 & 57 & 39 & 31 & 25 \\
\hline $\begin{array}{l}\text { Totals } \\
\text { Percent }\end{array}$ & $\begin{array}{r}104 \\
23.2\end{array}$ & $\begin{array}{r}144 \\
32.1\end{array}$ & $\begin{array}{r}84 \\
18.7\end{array}$ & $\begin{array}{r}61 \\
13.6\end{array}$ & $\begin{array}{r}56 \\
12.4\end{array}$ \\
\hline
\end{tabular}


More than anything else, these figures reflect the disastrous effects which inflation has had on salaried government officials between the years 1958 and 1968. (In 1966 the rate of inflation was over 600 percent.) Although there have been occasional salary increases, the latest being a $50 \%$ raise in April 1970, compensation levels still lag far behind price increases. While the data presented in Tables III(a) and III(b) are not as "hard" as one might wish, they do illuminate the dilemma faced by government officials who are compelled to find additional sources of income. The figures become still more significant if the general lack of incentives for correct behavior by government officials is considered. Salary increases are very difficult to obtain and truly meaningful increases may be impossible for the government to provide at this time. Rapid promotions are rarely possible. Government housing and vehicles are limited to a small fraction of al1 government employees. Trave1 and training opportunities are severely limited, particularly so for officials working outside Djakarta.

In addition to the shortage of incentives, applicable sanctions are also in comparatively short supply. Cultural norms effectively preclude punitive denial of the perquisites, however minor, that attend each position. Salary increases and promotions are all but automatic and the difficulty in removing someone from office is reflected in responses to the following question asked of higher civil servants:

\section{TABLE IV}

Responses of 120 Higher Regional Officials to the Question: "If the performance of your subordinates is poor or not good in any way, can you relieve them of their jobs?"

\begin{tabular}{lcc}
\hline \multicolumn{1}{c}{ Response } & Number & Percent \\
\hline $\begin{array}{l}\text { It is possible according to the regulations, } \\
\text { but I have never done it. }\end{array}$ & 88 & 73.3 \\
Sometimes & 13 & 10.8 \\
Usua11y & 19 & 15.8 \\
\hline
\end{tabular}

The responses require no interpretation except to point out that the common procedure for dealing with officials whose corrupt practices become open knowledge is to transfer them to new jobs before their activities gain wide attention.

Key Variables Identified by Indonesian Bureaucrats

The survey data indicate that Indonesian officials view low salaries as the prime factor behind corrupt practices. 
But the responses indicate that they are introspective and selfcritical of their own government's performance. About 50 percent of those surveyed blamed corruption on weak administration and a lack of effective government controls. Almost as many said civil servant mental attitudes were responsible. This last variable is not easy to unravel since the "mental attitude" (sikap mental) response encompasses such different concepts as traditional values, the lack of a public service ethic, greed, and dishonesty. Table V below provides a breakdown of their responses.

TABLE V

"In your opinion, what factors cause corruption?"

\begin{tabular}{|c|c|c|c|c|c|c|}
\hline \multirow[b]{2}{*}{$\begin{array}{l}\text { Province } \\
\text { (Number of } \\
\text { Respondents) }\end{array}$} & \multicolumn{6}{|c|}{ Corruption Causes Identified by Regional Officials } \\
\hline & $\begin{array}{l}\text { Low } \\
\text { Sala- } \\
\text { ries }\end{array}$ & $\begin{array}{l}\text { Civil } \\
\text { Servant } \\
\text { Mental } \\
\text { Attitudes }\end{array}$ & $\begin{array}{l}\text { Generally } \\
\text { Poor } \\
\text { Economic } \\
\text { Conditions }\end{array}$ & $\begin{array}{l}\text { Weak } \\
\text { Admin. and } \\
\text { Lack of } \\
\text { Controls }\end{array}$ & Other & $\begin{array}{l}\text { No } \\
\text { Answer }\end{array}$ \\
\hline \multicolumn{7}{|l|}{ West } \\
\hline Sumatra $(74) *$ & $\begin{array}{l}51 \\
69 \%\end{array}$ & $\begin{array}{l}53 \\
72 \%\end{array}$ & $\begin{array}{l}26 \\
35 \%\end{array}$ & $\begin{array}{l}44 \\
57 \%\end{array}$ & 11 & 6 \\
\hline \multicolumn{7}{|l|}{ South } \\
\hline Sulawesi (125)* & $\begin{array}{l}69 \\
55 \%\end{array}$ & $\begin{array}{l}50 \\
40 \%\end{array}$ & $\begin{array}{l}39 \\
31 \%\end{array}$ & $\begin{array}{l}58 \\
46 \%\end{array}$ & 12 & 12 \\
\hline \multicolumn{7}{|l|}{ Centra1 } \\
\hline Java (104)* & $\begin{array}{l}51 \\
49 \%\end{array}$ & $\begin{array}{l}35 \\
34 \%\end{array}$ & $\begin{array}{l}35 \\
34 \%\end{array}$ & $\begin{array}{l}43 \\
41 \%\end{array}$ & 17 & 11 \\
\hline $\begin{array}{c}\text { Totals } \\
(303)\end{array}$ & $\begin{array}{l}171 \\
56 \%\end{array}$ & $\begin{array}{r}142 \\
46 \%\end{array}$ & $\begin{array}{l}100 \\
32 \%\end{array}$ & $\begin{array}{l}145 \\
48 \%\end{array}$ & $\begin{array}{l}40 \\
13 \%\end{array}$ & $\begin{array}{l}29 \\
10 \%\end{array}$ \\
\hline
\end{tabular}

* These figures refer to the number of officials in each provincial sample. Multiple responses account for percentages which total more than 100 .

The response of a higher level official working in the Ministry of Home Affairs in South Sulawesi was not atypical. He suggested four reasons for corruption:

1. There are good opportunities for corruption.

2. It results from the general condition of the economy and low government salaries.

3. Our own administrative weaknesses facilitate corruption.

4. There is a lack of firmness by those who are charged with carrying out laws against corrupt officials with the result that corruption becomes a general phenomenon or a normal thing (jang biasa sadja). 20

20. Interview, December 1969. 
Structura1 Variables

There are obvious limitations on the reforming policy-makers' capacity to affect the abovementioned variables. They cannot change the history and culture of Indonesia, and aside from tariff, licensing and direct tax regulations, they have few alternatives in the economic. field under present conditions. However, there may be a close link between corruption and the kind of governmental structure which Indonesia has today. If this is true, then perhaps the options of government leaders are not as limited as they might at first appear to be.

Deductive reasoning suggests that a highly centralized governmental structure may not only make corruption possible, but necessary. Five elements of this argument are outlined below.

First, extremely limited numbers of decision-making centers place a premium on the ability of the public to draw attention to their problems and to get decisions from top leaders. Decisionmakers have a seller's market. The demand for decisions, many of them minor in nature, is much greater than they can suppiy. Money can be, and is, used to make particularistic demands more effective. This is rational in some senses--payment for performance--but disparities in purchasing power ensure that unequal treatment will be given to different publics.

Second, centralization leads to the issuance of more control regulations since top leaders cannot personally supervise the activities for which they are responsible. The multiplication of "preventive" controls through regulations establishes additional gatekeepers--officials who can extract a price at each gate. In sum, the more gates, the more widespread the need to use speed money.

Third, centralization lessens the likelihood that second and third-level regional governments will take initiatives in combatting corruption. They may not have the right to issue general corrective regulations, and, as our survey evidence indicates, perceived corruption at the center of government is itself a strong psychological deterrent to positive steps at lower levels.

Fourth, the results of a series of interviews by the author indicate that Indonesia's top decision-makers do not know with any precision the degree of corruption prevailing at lower levels nor. do they fully appreciate its impact on the general public. This is a result of the extent to which the upward flow of accurate information and frank reporting is discouraged within the government. With only vague notions of the degree and impact of corruption below them, they cannot readily be expected to take positive action.

Finally, the centralized revenue policy of the Indonesian government does little to enhance the responsibility of regional officials as they (the officials) perceive it. Figures for fiscal year 1969 1970 indicate that 1 ocal and regional governments received 52.6 percent of their budgets in the form of subsidies, 39.5 percent from revenue collections carried out by central government agencies in regions, and only 7.9 percent from their own efforts. ${ }^{1}$ It might

21. These problems are explored in much greater depth in $R$. Stafford Smith and Theodore M. Smith, "The Political Economy of Regional 
fairly be hypothesized that the less governments are responsible for financing themselves, the less concern their officials and local publics will show in seeing that funds are carefully handled. Stated another way, one tends to take better care of one's own money than one does that of someone else. It therefore seems highly probably that decentralization of rights to raise revenue would be followed by increased regional and local responsibility in the use of funds.

These points may be important in a policy sense because they suggest that limited steps toward the decentralization of decisionmaking could reduce the need for certain kinds of corruption. The contrary view, that increased local autonomy might, by reducing central control, actually result in increased corruption, has some plausibility. But there is a measure of irony here, since it is precisely some of those centralized controls which increase the need for corrupt behavior in the regions. Moreover, this argument rests on the unproven assumption that local controls would be less seriously enforced than central controls.

\section{Political Party Factors}

Political parties, particularly new political parties, have financing needs which have been only fitfully met in most lowincome countries. Their organizational investments and their purchase of support require a great deal of money, and often the only available means to obtain such working capital is to syphon it off the state. In narrow rational-bureaucratic terms this kind of corruption represents a serious loss. But in a broader perspective, it may represent unofficial investments in the political infrastructure (party development) which will open new, or strengthen established channels of interest articulation. Indonesia's last general elections in 1955 witnessed successful attempts by several parties, particularly the PNI, to divert state resources to their own campaign funds. ${ }^{2}$ The line between civil service and political party activity has never been sharply drawn in Indonesia. Government Regulation No. 6 of 1970 prohibits members of the armed forces, officials of the Defense Department, judges, public prosecutors and the state bank governor from joining political organizations, but the bulk of the civil service is free to join. Moreover, civil servants standing for election need not resign their positions until they are elected and accept membership in a legislative body (Presidential Decision of October 26,1970 ). Though some officials are troubled that the civil service should be involved in partisan politics, a series of interviews with provincial officials indicated that a majority of them will participate actively in the forthcoming July 1971 general elections.

and Urban Revenue Policy in Indonesia," (forthcoming).

22. See Herbert Feith, "Dynamics of Guided Democracy," in Ruth McVey, ed., Indonesia (New Haven: HRAF Press, 1963), p. 315. 
TABLE VI

Givil Servant and Student Responses to the

Question: "Do you expect to join in the upcoming general election activities?"

\begin{tabular}{|c|c|c|c|c|c|c|c|c|c|}
\hline \multicolumn{2}{|c|}{ Type of Respondent } & \multirow{2}{*}{$\frac{\text { Yes }}{71}$} & \multirow{2}{*}{$\frac{\%}{45.2}$} & \multirow{2}{*}{$\frac{\text { No }}{44}$} & \multirow{2}{*}{$\frac{\%}{28.0}$} & \multirow{2}{*}{$\begin{array}{l}\text { Don't } \\
\text { Know } \\
\text { Yet }\end{array}$} & \multirow{2}{*}{$\frac{\%}{24.2}$} & \multirow{2}{*}{$\begin{array}{l}\begin{array}{l}\text { No } \\
\text { Response }\end{array} \\
4\end{array}$} & \multirow{2}{*}{$\frac{\%}{2.5}$} \\
\hline Higher Leve 1 & $(157)$ & & & & & & & & \\
\hline Lower Level & $(146)$ & 75 & 51.4 & 34 & 23.3 & 32 & 21.9 & 5 & 3.4 \\
\hline $\begin{array}{l}\text { Subdistrict } \\
\text { Officers }\end{array}$ & $(257)$ & 129 & 50.2 & 72 & 28.0 & 45 & 17.5 & 11 & 4.3 \\
\hline $\begin{array}{c}\text { University } \\
\text { Students }\end{array}$ & $(554)$ & 249 & 44.9 & 94 & 17.0 & 203 & 36.6 & 6 & 1.1 \\
\hline
\end{tabular}

The data show that, more than a year before the elections, approximately half of the sample was already committed to joining the campaigns in some fashion or another. In many cases this participation will mean the providing of office equipment, supplies, vehicles and money to the political organizations supported by the official.

Beyond election needs, there are the day-to-day routine expenses which are required to keep a party functioning. Party leaders in Indonesia have sought and won extra-legal commercial privileges and the use of government facilities to serve their income needs and they are likely to continue this practice; military organizations follow the same strategy with even greater success. ${ }^{23}$

\section{Costs and Benefits of Corruption}

Full credit should be given to J. S. Nye for attempting to take the problem of corruption out of its moral context by suggesting a kind of analysis that might be useful to government leaders. ${ }^{4}$ Making use of his and some additional criteria for measurement, one can begin to assess the impact of corruption on development in Indonesia. Most of the tentative conclusions presented are impressionistic, but some data on elite attitudes toward corruption in the Indonesian government provide substance for an evaluation of political costs.

23. Bintoro Tjokroamidjojo, Sudjoko Prasodjo and Bambang Trijoso, "Masalah Korupsi" (Djakarta, March 1970, mimeo), p. 14.

24. J. S. Nye, "Corruption and Political Development: A CostBenefit Analysis," American Political Science Review, 61 (June 1967), pp. 417-428. 
Potential Benefits

Higher level corruption may be one means of accumulating capital. Assuming the possibility of this kind of corruption in Indonesia, the crucial question to be asked is whether or not this capital is being reinvested in Indonesia or being sent abroad. It is obvious that much of the capital is being reinvested in Indonesia. How much? We simply do not know, though one might be able to obtain some rough indicators through bank officials.

Limited enforcement of present business tax laws may allow businessmen to accumulate the necessary funds for new capital investment. Papanek notes in the case of Pakistan: "In practice, only 10 percent of actual industrial profits were collected in taxes, thus providing the spur and capital for industrial enterpreneurship."25 The Indonesian system of tax bargaining (tawar-menawar) which is carried on between tax officials and private businessmen clearly leaves some unofficial margin for the businessmen, but how much is uncertain. Informed Indonesian academics estimate that those larger indigenous companies which do pay taxes pay roughly 10 percent to 40 percent of what the assessed tax should be according to law. With the possible exception of many trading enterprises, much of this windfall is apparently being reinvested in Indonesia, particularly in urban housing and enterprises.

The selling of services at lower governmental levels represents an exchange of goods and services which in most cases actually permits a civil servant to perform his government function. Not only is this practice in harmony with traditional rural norms, but it allows lowsalaried officials to remain on the job. Certainly at the subdistrict and village levels the practice of paying for services rendered continues in full force. Usually the payments are in kind and the proximity of the subdistrict officer's house to the local market facilitates the exchange. There seems to be little resistance to this practice, though some was encountered at the village level in West Sumatra.

The use of "speed money" may facilitate more rapid foreign investment. Forced to work through normal bureaucratic channe1s, it may take several months or longer for foreign enterprises to get the necessary agreement and permission to establish factories. Unofficial incentives may hasten the process with the result that operations begin considerably sooner, benefitting both Indonesia and the foreign investor. It appears that competition among Indonesian agencies for the privilege of negotiating or approving investment offers is so great that al1 benefits of using "speed money" are 1ost--and along with them, many of the offers and potential offers. However, once investment agreements have been signed, it seems probable that this form of bribery pays dividends in getting production going.

25. Gustav Papanek, Pakistan's Development: Social Goals and Private Incentives (Cambridge: Harvard University Press, 1967), pp. 110 and 193. 
Potential Costs

Capital accumulated through high-level corruption may be wasted. There is considerable evidence from Latin American dictatorships and more recently from Vietnam that much of the accumulated capital in those areas finds its way to West European banks, a practice not entirely unknown in the United States. In such cases the loss for the country involved is obvious. As noted above, very little can be learned about this phenomenon in Indonesia. However, if there is a direct correlation between the flight of such capital and the instability of a country's government (as we might reasonably suspect there is), Indonesia's present degree of political stability provides some basis for optimism.

Investment may be channeled into sectors such as construction, not because of economic profitability, but because it may thus be easier to hide corruption. ${ }^{26}$ It is probably indisputable that construction contracts permit some "sharing" of resources, but it is almost impossible to begin to measure the amount of resource diversion caused by this. A careful review of building permits issued by offices of the public works department would provide clues, but not firm answers. The results of interviews carried out with several budgetary officials suggest that departments consistently attempt to hide increased personnel allocations in construction projects, but it seems overly rigid to regard this routine strategy as corruption.

Corruption may squander the important asset of political legitimacy which most governments seek to preserve and build on. One of the major tasks of any regime is the building of its own legitimacy, a resource which will enable it to gain more easily the support and the assistance of the public in connection with development (at the expenditure of fewer economic and political resources). It may or may not be true, but many Indonesians in the Outer Islands believe that most of the corruption in Indonesia is located in Djakarta. The fact that they believe this and that few serious steps have been taken to control corruption tends to reduce the legitimacy of the Central Government in their eyes. ${ }^{2} 7$

Corruption may tend to destroy some of a new nation's greatest potential assets, the enthusiasm, idealism and sympathy of its youth and students. ${ }^{2}$ ' In the event that the idealism and enthusiasm of the younger generation turns to cynicism, not only political stability but long run economic development efforts are bound to be affected. The students will be the future political leaders and economic modernizers. The Djakarta demonstrations of January 1970 indicate the reality of this concern in the capital. Some preliminary data from university students in Sumatra, Sulawesi and Java suggest that most Indonesian students are aware of the problem and critical of corruption in the government.

26. Nye, "Corruption and Political Development," p. 421.

27. Based on interviews with government officials in West Sumatra and South Sulawesi.

28. Ronald Wraith and Edgar Simpkins, Corruption in Developing Countries (London: AIlen and Unwin Ltd., 1963). 
TABLE VII (a)

University Student Response to the Question:

"Have you ever discussed the problem of corruption with anyone?"

\begin{tabular}{lllll}
\hline & No & No Response \\
\hline $447 \quad 80.7 \%$ & 101 & $18.2 \%$ & 6 & $1.1 \%$ \\
\hline
\end{tabular}

TABLE VII (b)

University Student Response to the Question:

"In your opinion does corruption constitute an important problem in connection with economic development?"

\begin{tabular}{llllllll}
\hline Yes & No & & Don't Know & No Response \\
\hline 529 & $95.5 \%$ & 11 & $2.0 \%$ & 7 & $1.3 \%$ & 7 & $1.3 \%$ \\
\hline
\end{tabular}

In sum, students seem to discuss corruption and they seem to be concerned about its impact on economic development. In response to another question in which they were asked to identify the main problems facing Indonesia today, a surprising number mentioned the problem of corruption first. 29

Corruption may alienate civil servants and cause them to reduce their efforts and support for the government's policies. The loyalty and enthusiasm of capable, government officials is a desirable resource for any regime to have. But such loyalty is never guaranteed and the literature on bureaucracy suggests that bureaucracies, as distinct sectors of the polity, can sometimes be very effective in their demands. How does corruption in Indonesia's government affect its civil servants? There are no good measurements of the support

29. The student interviews were divided evenly among three provincial universities: Andalas (West Sumatra), Hasanuddin (South Sulawesi), and Diponegoro (Central Java). Third-year students from the faculties of medicine, economics, law, agriculture, and the social sciences were selected as respondents. The responses are all the more significant in that most of them were given prior to January 1970, when corruption became a national political is sue. 
which Indonesian civil servants give to their government, but again some data suggest that corruption is a matter of much concern to them. Table VIII(a) indicates that the subject is widely discussed; Table VIII(b) shows a surprising number of officials who have discussed the problem of corruption with their superiors; and Table VIII(c) reflects a broad, general concern over corruption in relation to economic development.

\section{TABLE VIII (a)}

Civil Servant Response to the Question: "Have you ever discussed corruption with anyone?"

\begin{tabular}{lcccc}
\hline \hline $\begin{array}{l}\text { Type of Regional } \\
\text { Civil Servant }\end{array}$ & Yes & $\begin{array}{l}\text { No or } \\
\text { Not Yet }\end{array}$ & $\begin{array}{c}\text { No } \\
\text { Response }\end{array}$ \\
\hline Economic Planners & $(54)$ & 50 & 3 & 1 \\
Higher Leve1 & $(157)$ & $92 \%$ & $6 \%$ & 3 \\
Lower Leve1 & $(146)$ & $72 \%$ & 41 & 7 \\
& & 90 & $26 \%$ & 49 \\
Totals & $(357)$ & $62 \%$ & $33 \%$ & 11 \\
Percent & & 253 & 93 & $3 \%$ \\
\hline
\end{tabular}

TABLE VIII(b)

Civil Servant Response to the Question: "If you have discussed corruption, with whom?"*

\begin{tabular}{|c|c|c|c|c|c|}
\hline $\begin{array}{l}\text { Type of Regional } \\
\text { Civil Servant }\end{array}$ & Superior & Subordinate & Family & Colleagues & Friends \\
\hline $\begin{array}{c}\text { Economic Planners } \\
(54)\end{array}$ & 19 & 19 & 25 & 43 & 29 \\
\hline $\begin{array}{l}\text { Higher Level } \\
\text { (157) }\end{array}$ & 35 & 28 & 34 & 71 & 54 \\
\hline \multirow[t]{2}{*}{$\begin{array}{l}\text { Lower Leve } 1 \\
\qquad(146)\end{array}$} & 17 & 17 & 20 & 50 & 53 \\
\hline & 71 & 64 & 79 & 164 & 136 \\
\hline
\end{tabular}

* Note: Multiple Responses were Permitted. 
TABLE VIII (c)

Civil Servant Response to the Question: "In

your opinion does corruption constitute

an important problem in connection

with economic development?"

\begin{tabular}{lccccc}
\hline $\begin{array}{l}\text { Type of Regional } \\
\text { Civi1 Servant }\end{array}$ & Yes & No & $\begin{array}{l}\text { Don't } \\
\text { Know }\end{array}$ & $\begin{array}{l}\text { No } \\
\text { Response }\end{array}$ \\
\hline Economic Planners & $(54)$ & 52 & 0 & 1 & 1 \\
Higher Leve1 & $(157)$ & 152 & $96 \%$ & $0 \%$ & 3 \\
Lower Leve1 & $(146)$ & 130 & $97 \%$ & $9 \%$ & 7 \\
& & $89 \%$ & $6 \%$ & 0 & 11 \\
\cline { 2 - 6 } Totals & $(357)$ & 334 & 11 & 1 & $3 \%$ \\
Percent & & $94 \%$ & $3 \%$ & & \\
\hline
\end{tabular}

Though not shown here, the data are consistent across the three provinces of West Sumatra, South Sulawesi, and Central Java. Nearly a11 officials are unhappy with present levels of corruption; some are angry that stronger measures have not yet been taken to lessen the frequency and amount of corruption. The data also suggest that there is general receptivity to increased control mechanisms should they be introduced.

\section{Conclusions}

Contrary to the views of Furnivall and others, corruption (by its current definition) was widespread in the Netherlands Indies. The legal system imposed by the Dutch left traditional patrimonial relationships largely untouched. For the Dutch to have destroyed them through attempts at direct rule would have resulted in chaos. Thus the "abuses" of the patrimonial system persisted through the colonial period and because social norms do not change as rapidly as statutory law, many of them continue today.

Given these traditions, the stimulus of low salaries, and expanded government functions, it is obvious that major investments would be required if a decision were to be made today to eradicate corruption. What kind of investments? Direct investments in governmental salaries, legal institutions, political parties, education, control mechanisms, and possibly even structural changes in the bureaucracy. The magnitude of these investments can best be understood by isolating one variable, that of government salaries and benefits. A doubling of salaries and benefits would require a total personnel expenditure in the neighborhood of $\mathrm{Rp} .400$ bilition--considerably more than total domestic revenues at present. ${ }^{30}$ Even

30. Revenues for fiscal year 1969-1970 were Rp. 309.4 billion, or 
if salary increases of this magnitude were feasible, there are many other important variables affecting the incidence of corruption and only part of the problem would be solved.

On the whole, corruption in Indonesia appears to present more of a recurring political problem than an economic one. It undermines the legitimacy of the government in the eyes of the young, educated elite and most civil servants. In the case of the latter, it is assumed, but cannot be proven, that certain types of corruption substantially reduce bureaucratic productivity. Furthermore, scores of interview responses indicate that corruption reduces support for the government among elites at the province and regency level. Final$1 y$, the survey data suggest that concern over the problem of corruption runs much deeper than is superficially apparent.

The Suharto government has adopted a low-cost strategy to cope with the problem. High civilian and military officials must now list their personal wealth annually; ${ }^{31}$ new anti-corruption laws have been proposed; selected state organizations are being investigated; and the President has obligated himself to "lead the fight" personal1y. The strategy is a realistic one which is designed to meet immediate political demands and short-range objectives.

But corruption will continue to recur as a political issue, requiring additional investments by the government. Because much of the indigenous concern over corruption in Indonesia is at present latent or unexpressed, there is good reason to believe that with the further development of political parties, the press, and associational interest groups, investments to limit corrupt practices will need to be larger in the future.

about $\$ 818.5$ million. A doubling of government salaries would provide a college-educated bureau chief with an increase to on $1 y$ $\$ 80$ from the present $\$ 40$ per month. Most civil servants and military personnel would receive much less. Data on revenues were obtained from "Pelaksanaan Tahun Pertama Repelita," an appendix to the President's National Day speech, August 16, 1970, p. 72 .

34. Presidential Decision, Number 52, August 3, 1970. 